\title{
Diversificação de Estruturas Industriais Localizadas: um estudo de caso para o Estado de Santa Catarina
}

Pablo Felipe Bittencourt ${ }^{1}$

Renato Ramos Campos ${ }^{2}$

\begin{abstract}
Resumo: Este estudo contribui no esforço de sistematizar informações sobre as estruturas produtivas aglomeradas em Santa Catarina. Seus objetivos são (i) identificar aglomerações consistentes e (ii) apontar características internas que as diferenciem. Para o primeiro, uma metodologia foi desenvolvida com base em contribuições existentes na literatura. Para o segundo, além da sistematização de diversas informações estatísticas, foi desenvolvido um Indicador do Adensamento Estrutural. A aplicação da metodologia revelou 32 aglomerações produtivas, especializadas em 10 setores da atividade de transformação e localizadas em 16 microrregiões catarinenses. Os resultados permitiram uma diferenciação nas prioridades normativas a aglomerações localizadas em regiões mais ou menos industrializadas.
\end{abstract}

Palavras-chave: aglomerações produtivas; localização industrial e indústria catarinense.

\section{Diversification of Localized Industrial Structures: a case study for the Santa Catarina State}

\begin{abstract}
This essay systematizes information on agglomerated productive structures in the State of Santa Catarina (Brazil). Its objectives are (i) to identify consistent agglomerations and (ii) to point out some internal distinguishing characteristics. For the first objective, a methodology was developed based on other authors' contributions. For the second, besides the systematization of existing data, a Structural Densification Index was also developed. The developed methodology showed 32 productive agglomerations, divided into 10 sectors of transformation activity, and located at 16 Santa Catarina's micro regions. The results allow us to differentiate normative priorities between agglomerations located in more or less industrialized regions.
\end{abstract}

1 Doutorando em Economia pela UFF e bolsista CAPES. E-mail: pablofelipe.bittencourt@gmail.com.

2 Professor do Departamento de Economia da UFSC. E-mail: recampos@cse.ufsc.br. 
Key-words: productive agglomeration; industrial localization and Santa Catarina industry.

JEL: R1; R12

\section{Introdução}

No âmbito da organização industrial, este artigo discute propriedades e a dinâmica das concentrações produtivas. Pressupõe-se que aglomerações geográficas são espaços indutores de maior nível de eficiência produtiva, pois estimulam naturalmente processos interativos e favorecem o aprendizado tecnológico.

A literatura atual de economia industrial reconhece que, em muitos casos, a consolidação de estruturas produtivas aglomeradas é explicada por um conjunto de características sócio-econômico-culturais específicas, que resultam num padrão particular de especialização produtiva. Desta maneira, articulamse, complementarmente ao enfoque setorial, elementos do território que são relevantes para a dinâmica industrial localizada.

Do ponto de vista da potencialidade dos ganhos interativos, metodologicamente, torna-se importante a melhor identificação possível da estrutura interna das aglomerações, porquanto características como tamanho das firmas, padrão de especialização e elos da cadeia produtiva apontam o potencial interativo vertical ou horizontal, por exemplo, o que pode servir de baliza ao desenho de políticas industriais.

A estrutura industrial catarinense é marcada pela presença de ampla gama de micro, pequenas e médias firmas coexistindo com grandes empresas líderes em seus segmentos industriais. Adicionalmente, são bastante evidentes as características de diversificação setorial associada a especializações regionais (Campos et al. 2002). Contudo, o interior destas regiões apresenta significativos processos de diversificação industrial, quer por decorrência das especificidades de seus processos endógenos de desenvolvimento, quer por suas relações com mercados nacional e internacional.

Considerando o exposto, o artigo pretende verificar a adequação de procedimentos metodológicos específicos para identificar aglomerações produtivas representativas da diversidade e densidade industrial do Estado e que, por isso, possam servir de objeto de política industrial. Além disso, pretende-se também explorar formas quantitativas para avaliar o adensamento estrutural nessas aglomerações.

Foi utilizada a base de dados da Relação Anual de Informações Sociais do Ministério do Trabalho e Emprego (RAIS/MTE), por fornecer bons indicadores relativos à localização da estrutura produtiva brasileira, em vários níveis de desagregação regional, chegando-se ao nível do município. Setorialmente, os 
dados são classificados a partir da CNAE nos níveis de seção, divisão, grupo e classe das atividades econômicas, o que permite a identificação do padrão de especialização das regiões. Ademais, oferece dados sobre o porte das firmas, evidenciando diferenças entre regiões de mesma especialização, por exemplo. $\mathrm{O}$ ano de referência é $2003^{3}$.

Além dessa seção introdutória, o trabalho contém outras quatro. A que se segue apresenta o modelo de análise. A seção três exibe o "índice de adensamento estrutural" (IAE), que pretende contribuir na busca de instrumentos para a identificação e comparação das complexidades internas das aglomerações. Na seção quatro, uma breve caracterização da indústria catarinense introduz a apresentação das aglomerações produtivas identificadas. Na última seção estão as conclusões.

\section{O Modelo de Análise}

Índices de concentração como o gini locacional (Gl) e o quociente locacional (QL) vêm sendo amplamente utilizados recentemente com o objetivo de mapear distribuições espaciais, identificar especializações regionais, analisar movimentos de deslocamento regionais de atividades econômicas e avaliar processos de diversificação produtiva regional (Suzigan et al. 200 3a). Com o QL4 , é possível comparar a participação percentual de uma região “j” qualquer em um setor "i” com a participação percentual da mesma região "j” na economia de referência. Valores de QL maiores do que 1 em uma região indicariam setores mais importantes relativamente a outros nessa região.

O cálculo do QL neste artigo indica a concentração relativa de uma determinada indústria numa microrregião comparativamente à participação desta mesma indústria no Estado de Santa Catarina.

O método proposto por Suzigan utiliza o índice de gini locacional (GL) e o índice de especialização (QL), combinados com variáveis de controle para identificação, delimitação geográfica e caracterização estrutural de sistemas produtivos locais (Suzigan et al. 2004). As bases de dados de referência são da RAIS/MTE e da PIA/IBGE5 5 . O método proposto por Britto (2003), apesar de não considerar o índice de gini locacional, utiliza o índice de especialização (QL) e impõe critérios através de variáveis de superposição para identificar aglomerações com características de maior complexidade estrutural.

\footnotetext{
3 Entre os problemas da base de dados, destacamos: a 'captação apenas dos postos formais de trabalhos'; O método de 'autoclassificação' que gera dificuldades, pois permite que empresas ofertantes de vários produtos escolham sua classificação; além do que, várias unidades produtivas de uma mesma empresa podem ser classificadas num mesmo endereço, dificultando a identificação da aglomeração (Suzigan 2004).

4 Para uma discussão metodológica do QL, ver Haddad (1989).

5 Pesquisa Anual Industrial/Instituto Brasileiro de Geografia e Estatística.
} 
O uso exclusivo dos índices de concentração, com base no número de empregados, apresenta dois problemas: (a) uma 'região pequena' poderia mostrar um índice elevado em virtude da presença de apenas uma empresa de médio ou grande porte; e (b) haveria dificuldade de 'identificar especializações em estruturas produtivas bastante diversificadas', em regiões muito industrializadas com altos níveis de emprego (Suzigan et al. 2004). Por isso, são utilizadas variáveis de controle. As usuais são duas. Uma referente à importância local da aglomeração segundo a participação do emprego setorial no total do emprego no local. As atividades produtivas podem ser agregadas por "classes" ou "divisões" da CNAE e o local pode ser formado pelo município ou pela agregação de municípios em microrregiões (definidas pelo IBGE), ou ainda outra agregação permitida pelas informações que servem de base para a análise, Outra variável de controle pode ser a definição de um número mínimo de estabelecimentos para local, caracterizando desse modo a densidade da aglomeração.

Outro aspecto a considerar sobre as características das estruturas produtivas locais que criam bases para relações entre os agentes produtivos é a variedade de atividades produtivas presentes no espaço. Há que se identificar, portanto as etapas da cadeia produtiva presentes no local, ou a diversidade dessas atividades, caracterizando estruturas produtivas locais com predominância de relações verticais (cadeia) ou horizontais (Britto \& Albuquerque 2002).

Levando em conta essas qualidades e debilidades dos índices de concentração e a utilização de variáveis de controle que complementam a análise, foram adotados os seguintes procedimentos para a identificação das aglomerações catarinenses. O primeiro foi (i) o cálculo do quociente locacional:

$\mathrm{QL}=$ (EMP divisão (i) na mic.(j) / EMP mic (j)) / (EMP na divisão (i) no Estado/ total do EMP do Estado)

\section{Em que:}

$\mathrm{EMP}$ = número de trabalhadores empregados; e

Mic = a microrregião, local geográfico de referência.

Portanto, o território foi definido no nível das microrregiões geográficas do IBGE (Figura 1 do Anexo 1) e a atividade produtiva definida no nível da divisão/CNAE - dois dígitos.

Foi utilizado um segundo procedimento com o objetivo de (ii) excluir as concentrações com baixa relevância no emprego em relação ao total do setor no Estado.

Para a seleção das aglomerações com base nestes dois procedimentos, foram definidos os seguintes valores mínimos: um quociente locacional $>1 \mathrm{e}$ a participação no total de empregados de seu setor industrial maior do que $2,5 \%$ do 
total do Estado. ${ }^{6}$ Os resultados apontaram 103 concentrações em 25 divisões/ CNAE localizadas em 18 das 20 microrregiões catarinenses. ${ }^{7}$

O terceiro procedimento (iii) consistiu em reagrupar as 25 divisões/CNAE conforme características de semelhança dos produtos e processos produtivos para avaliar a presença de elos da cadeia produtiva no local. Tal reagrupamento proporcionou a identificação de 11 atividades industriais que serviram de base para os procedimentos seguintes. Permaneceram as determinadas atividades industriais: têxtil/vestuário, eletro-metal-mecânico, móveis e madeira, fabricação de minerais não-metálicos, borracha e plástico, couro/calçados, químico, alimentício, informática, coque e refino de petróleo, reciclagem e papel e celulose. ${ }^{8}$

Destas atividades industriais foram excluídas as divisões/CNAE de "coque e refino de petróleo" e de "reciclagem", por terem pequena participação no VTI estadual. Foram excluídas também as divisões de "papel e celulose”, de “alimentos e bebida”, ${ }^{9}$ por se tratarem de atividades cuja organização produtiva é integrada em grandes empresas. Restaram, portanto 88 concentrações, em 22 divisões/CNAE, agregadas em nove atividades industriais objetos dos passos metodológicos seguintes.

Partindo da agregação definida no procedimento anterior, verificaram-se, para estas atividades, em cada microrregião, os seguintes critérios: (v) possuir algum grau de importância para a região, medido pelo número de empregos gerados pelo setor específico naquele local em relação ao número total de trabalhadores empregados na microrregião; e (vi) apresentar densidade segundo o número de empresas do setor na microrregião.

Para a definição dos parâmetros mínimos dos dois procedimentos, consideraram-se a intensidade do uso de mão-de-obra e a tendência de internalização na firma das várias etapas do processo produtivo. Assim, níveis diferenciados de (v) e (vi) foram exigidos para os dois grupos: a) no caso dos produtores de bens de consumo (móveis, madeira e papel e celulose, cerâmica, têxtilconfecções, couro-calçados e alimentos) a participação do emprego no total da microrregião deveria ser superior a 1,5\% e o número mínimo de empresas de 25 (vinte e cinco); b) no caso dos produtores de insumos e bens de capital (metal-mecânico, plástico e borracha, atividades de informática e produtos químicos), a participação do emprego no total da microrregião não poderia ser menor que o,6\% e o número de empresas menor do que 50.

6 Este foi resultado da observação empírica e definido com o objetivo de obter um número de aglomerações que expressasse a diversidade setorial da estrutura industrial catarinense.

7 Foram consideradas todas as divisões/CNAE da transformação industrial, além da divisão 72 de Atividades de Informática e da divisão 02 de Pesca, Aqüicultura e Serviços Relacionados.

8 Além disso, observaram-se as concentrações formadas pelas divisões/CNAE de "edição, impressão e reprodução de gravações", e "as atividades do fumo". Contudo, não fazem parte do artigo, por contarem com VTI's excessivamente reduzidos.

9 Apenas atividades relacionadas ao beneficiamento de pescado foram consideradas. 
O último procedimento (vii) foi observar a localização da atividade industrial no nível do município. O objetivo foi incluir como parte da aglomeração o conjunto de firmas localizadas em municípios contíguos, mas que não faziam parte da microrregião/ atividade selecionada pelos critérios acima.

\section{2. $O$ Índice de Adensamento Estrutural}

Apoiado na hipótese de que a proximidade geográfica estimula interações que favorecem o aprendizado tecnológico da firma e que esse processo se traduz em maiores níveis de eficiência produtiva, e baseado nas noções de cluster vertical e horizontal (Britto \& Albuquerque 2002), desenvolveu-se o "Índice de Adensamento Estrutural" (IAE). Os clusters "verticais" podem favorecer as relações produtor-usuário em condições de proximidade espacial. Os clusters "horizontais" indicam a concentração de diversas atividades similares em um mesmo local, o que possibilita o compartilhamento de recursos específicos disponíveis na região.

Nessa linha, o IAE avança ao diferenciar as estruturas produtivas selecionadas a partir de suas complexidades internas ao ponderar a presença de atividades a montante da cadeia produtiva com a gama de estabelecimentos ligados à atividade principal.

É um indicador das diversidades das cadeias produtivas locais que possui como base a diversificação da estrutura produtiva setorial do Estado. O IAE é formado por dois componentes, como segue:

$$
\begin{array}{r}
\mathrm{IAE}=\left\{\left[\left(\sum \text { PMEmic } / \sum \text { PMEest }\right)+\left(\sum \text { TMEmic } / \sum \text { TMEest }\right)\right]+\right. \\
\left.\left[\left(\sum \text { PSmic } / \sum \text { PSest }\right)+\left(\sum \text { TSmic } / \sum \text { TSest }\right)\right]\right\}{ }^{*} 1000
\end{array}
$$

Em que:

PMEmic: é o número de estabelecimentos produtores de máquinas e equipamentos (M\&E) do setor na microrregião;

PMEest: é o número total de estabelecimentos produtores de M\&E do setor no Estado;

TMEmic: é o número de empregados nas produtoras de M\&E do setor na microrregião;

TMEest: é o número de estabelecimentos dos produtores em M\&E no Estado;

PSmic: é o número de estabelecimentos na(s) divisão(ões) do setor na microrregião;

PSest: é o número de estabelecimentos na(s) divisão(ões) do setor no Estado; 
TSmic: é o número de empregados na(s) divisão(ões) do setor na microrregião;

TSest: é o número de empregados na(s) divisão(ões) do setor no Estado.

O primeiro componente contém a soma da expressão ( $\sum$ PMEmic / $\sum$ PMEest), que procura diferenciar as estruturas a partir do número de fornecedores de máquinas e equipamentos, com a expressão ( $\sum$ TMEmic / $\sum$ TMEest), que considera o número de empregados dos produtores de máquinas e equipamentos para determinado setor na microrregião. Essa segunda expressão, somada à primeira, cumpre o papel de ajustar possíveis erros de superestimação da complexidade local, em virtude da possível presença de um número elevado de micro e pequenas empresas. Da mesma forma, procedeu-se no segundo componente $\left[\left(\sum\right.\right.$ PSmic $/ \sum$ PSest $)+\left(\sum\right.$ TSmic $/ \sum$ TSest $)$, que considera as divisões/CNAE (dois dígitos) específicas do setor/local analisado e contribui na magnitude do índice, segundo a densidade setorial da estrutura local. A referência (denominador) é o Estado de Santa Catarina. Índices mais elevados indicam estruturas produtivas mais densas e complexas, supostamente, com maior potencial de interação nos processos de aprendizagem (Lundval 1988).

Para calcular o índice, valeu-se da base de dados da RAIS/MTE obtendo-se informações relativas às atividades específicas de cada aglomeração. Utilizouse também a base estatística da Associação Brasileira de Produtores de Máquinas e Equipamentos (ABIMAQ), que permitiu a identificação do número de produtores de M\&E para a atividade industrial, bem como, seus setores de atuação e as respectivas localizações (município). As informações relativas ao porte das empresas (número de empregados) foram obtidas via contatos telefônicos. Foram considerados produtores 'locais' de M\&E, aqueles com instalações na microrregião em análise ou em municípios imediatamente vizinhos às microrregiões.

O índice pode variar de zero a 1000, dependendo do grau de concentração de produtores de M\&E e produtores dos bens específicos no Estado em cada uma das atividades estudadas (madeira, plástico, móveis etc...). A aplicação foi possível somente para as atividades de têxteis e confecções, móveis e madeira, plásticos e cerâmicos, em virtude da falta de informações estatísticas confiáveis sobre o número de produtores de M\&E para as outras atividades. 


\section{A Indústria Catarinense e a Identificação das Estrutu- ras Produtivas}

O início da formação da estrutura industrial catarinense data da segunda metade do século XIX. Na época, o influxo migratório de origem europeia para a região litorânea, organizado em pequenas propriedades rurais, combinou-se à exploração intensiva da agropecuária, da madeira e da erva-mate no planalto catarinense. A região Oeste começou a ser ocupada somente a partir do início do século XX, com a expansão da fronteira agrícola do país em direção ao Centro-Oeste.

O desenvolvimento da atividade industrial no Estado, marcado pela especialização regional, esteve muito mais articulado ao processo de industrialização nacional do que, supostamente, a uma dinâmica interna específica (Campos et al. 2002). O surgimento das diversas especializações regionais possui motivos particulares, entre eles: (i) a disponibilidade de recursos naturais, no caso das madeireiras, cerâmicas e couro/calçadista, (ii) habilidade técnica dos primeiros imigrantes, com destaque para os descendentes alemães da região Nordeste do Estado nas indústrias eletro-metal-mecânica e têxtil/ vestuarista, mas também dos descendentes italianos na região Sul na produção de cerâmica de revestimento, (iii) a disponibilidade de mão de obra, na especialização vestuarista da região de Criciúma e Tubarão no Sul do Estado, (iv) articulações do arranjo institucional, na figura do desenvolvimento das atividades de software na capital do Estado, além do (v) grau de difusão da base técnica de conhecimentos, (vi) de características de empreendedorismo local, e a (vii) proximidade com aglomerações produtivas rio-grandenses.

A formação atual mantém as características de especialização regional combinadas à diversificação da estrutura produtiva catarinense. Essa última é retratada na Tabela 1 com a evolução recente da porcentagem do valor da transformação industrial (VTI) setorial em relação ao total do Estado e do Brasil. 


\section{TABELA 1- PARTICIPAÇÃO SETORIAL DO VTI NO TOTAL DE SC E BRASIL 1998-2005}

\begin{tabular}{|c|c|c|c|c|c|c|c|c|}
\hline \multirow{2}{*}{ ATIVIDADE } & \multicolumn{4}{|c|}{ \% No total do Estado } & \multicolumn{4}{|c|}{ \% No total do País } \\
\hline & 1998 & 2000 & 2002 & 2005 & 1998 & 2000 & 2002 & 2005 \\
\hline Indústria de transformação & 98 & 97,7 & 98,9 & 98,5 & 4,8 & 4,41 & 5,1 & 4,6 \\
\hline Alimentos e bebidas & 22,2 & 18,6 & 22,8 & 25,9 & 5,8 & 5,65 & 6,8 & 7,1 \\
\hline Fumo & 1,8 & 2,7 & 1,7 & 2,1 & 9,2 & 14,8 & 9,7 & 13,9 \\
\hline Produtos têxteis & 9,5 & 10,5 & 8,7 & 7,1 & 14,6 & 15,72 & 16,7 & 15,6 \\
\hline Artigos do vestuário & 10,3 & 9,2 & 7,4 & 8,0 & 22,7 & 20,66 & 23,3 & 25,5 \\
\hline Couro e calçados & 0,5 & 0,6 & 0,7 & 0,7 & 1,3 & 1,31 & 1,5 & 1,9 \\
\hline Madeira & 4 & 4,2 & 5,8 & 4,9 & 16,7 & 15,5 & 18,9 & 15,5 \\
\hline Celulose e papel & 5,4 & 6,8 & 7,1 & 4,9 & 7,3 & 6,8 & 7,5 & 6,6 \\
\hline Edição, impressão e reprodução de gravações & 1,1 & 1,3 & 1,0 & 1,5 & 1,0 & 1,3 & 1,4 & 2,2 \\
\hline Coque e refino de petróleo & o & 0,1 & 0,0 & 0,2 & 0,0 & 0,02 & 0,0 & 0,1 \\
\hline Produtos químicos & 2,1 & 2,3 & 2,4 & 2,6 & 0,8 & 0,8 & 1,0 & 1,1 \\
\hline Borracha e plástico & 6,8 & 6,2 & 5,2 & 5,3 & 7,7 & 7,46 & 7,9 & 6,8 \\
\hline Minerais não-metálicos & 6 & 5,3 & 5,3 & 4,2 & 7 & 6,08 & 6,4 & 6,4 \\
\hline Metalurgia básica & 3,8 & 1,8 & 1,3 & 3,2 & 3,2 & 1,24 & 0,9 & 1,7 \\
\hline Produtos de metal - exclusive máquinas & 2,5 & 2,8 & 2,8 & 3,6 & 2,9 & 3,6 & 3,8 & 4,4 \\
\hline Máquinas e equipamentos & 11 & 11,5 & 12,3 & 9,5 & 8,1 & 9,3 & 10,1 & 8,1 \\
\hline $\begin{array}{l}\text { Máquinas para escritório e equipamentos de } \\
\text { informática }\end{array}$ & 0,1 & 0,1 & 0,1 & 0,1 & 0,5 & 0,2 & 0,5 & 0,6 \\
\hline Máquinas, aparelhos e equipamentos elétricos & 4,3 & 3,7 & 4,6 & 5,8 & 7,3 & 7 & 10 & 11,3 \\
\hline $\begin{array}{l}\text { Material eletrônico e de aparelhos de } \\
\text { comunicação }\end{array}$ & 0,5 & 0,7 & 0,5 & 0,5 & 0,8 & 1 & 1 & 1,2 \\
\hline Equipamentos de instrumentação & 0,5 & 0,7 & 0,9 & 0,5 & 2,6 & 3,3 & 5,2 & 2,6 \\
\hline Veículos automotores, reboques e carrocerias & 1,9 & 4,7 & 3,6 & 4,4 & 1,1 & 2,6 & 2,5 & 2,5 \\
\hline Outros equipamentos de transporte & 0,2 & 0,2 & 0,4 & 0,3 & 0,8 & 0,5 & 0,8 & 0,9 \\
\hline Móveis e indústrias diversas & 3,4 & 3,9 & 4,2 & 3,2 & 6,8 & 7,9 & 10,9 & 9,1 \\
\hline Reciclagem & o & o & 0,1 & 0,2 & 1,5 & 2 & 6 & 10,1 \\
\hline Indústrias extrativas & 2 & 2,3 & 1,1 & 1,5 & 2,3 & 1,72 & 1,66 & 1,5 \\
\hline Total & 100 & 100 & 100 & 100 & 4,7 & 4,26 & 4,3 & 4,4 \\
\hline
\end{tabular}

Fonte: Elaboração própria com base nos dados da PIA 1998-2005 - SC

Conforme a Tabela, em 2005, aproximadamente metade do VTI catarinense concentrou-se nos setores de alimentos $(25,9)$, máquinas e equipamentos $(9,5)$, vestuarista $(8,0)$ e têxtil $(7,1)$. São destaques também os tradicionais de base florestal, de papel e celulose $(4,9)$, madeira e $(4,9)$ móveis $(3,2)$; e borracha/plástico $(5,3)$ e minerais não-metálicos $(4,2)$. Com exceção do setor de alimentos, a evolução dos dados revela a tendência de decréscimo da representatividade de setores mais tradicionais em benefício daqueles com maior 
potencial de desenvolvimento tecnológico, como de máquinas, aparelhos e materiais elétricos e de veículos automotores. Ainda que incipiente, esse movimento sugere ampliação da diversificação industrial do Estado.

Em âmbito nacional, são representativas as atividades: têxteis e do vestuário e de móveis e madeira, mas também, de alimentos, papel e celulose, minerais não-metálicos, de borracha/plástico e do complexo eletro-mecânico, especialmente, os segmentos de "máquinas e equipamentos" e "máquinas, aparelhos e materiais elétricos". A leitura da tabela pode surpreender pelo decréscimo da representatividade das indústrias de transformação e de extração combinar-se a movimento contrário na maior parte dos setores vistos de forma desagregada. Tais movimentos, aparentemente incompatíveis, são explicados pelos diferentes graus de diversificação industrial da economia catarinense e da nacional, de maneira que as expressivas ampliações de representatividade de todo o complexo têxtil/vestuarista podem ter sido compensadas pelo, aparentemente, inexpressivo declínio da representatividade do setor de metalurgia básica, uma vez que esse representa fatia expressiva do VTI nacional, (8\%).

Com as informações da Tabela 2, passamos a analisar características geográficas da econômica catarinense. $\mathrm{O}$ breve panorama que se segue revela onde estão as grandes concentrações populacionais e da riqueza.

Nota-se que, do maior para o menor IDH, a variação não chega a o,1. Destacam-se negativamente as microrregiões que compõem a mesorregião serrana, de Curitibanos e Campos de Lages. E positivamente as microrregiões de Florianópolis, Joinville e Blumenau, que combinam os maiores PIB's absolutos, as maiores populações e os maiores IDH's. No caso de Joinville e Blumenau, é enfatizado o papel da transformação industrial, enquanto que, em Florianópolis, o turismo associado ao aparelho estatal é o destaque.

A mesorregião Oeste ${ }^{10}$ é composta pelas microrregiões de Xanxerê, São Miguel d'Oeste, Concórdia, Joaçaba e Chapecó. As duas últimas concentram 16\% do PIB e da área geográfica e 12,5\% da população do Estado. Uma característica interessante é a alta concentração da renda. Dos 27 municípios que compõem a microrregião de Joaçaba, três concentram municípios que compõem a microrregião de Joaçaba, três concentram mais da metade do PIB local, respectivamente, Caçador, Videira e Joaçaba. Ao passo que na microrregião de Chapecó, composta por 39 municípios, mais de 60\% do PIB está concentrado no município de Chapecó. 
TABELA 2- POPULAÇÃO, IDH E PIB DAS MICRORREGIÕES CATARINENSES

\begin{tabular}{|c|c|c|c|c|c|}
\hline Microrregião & $\begin{array}{l}\text { Área Km² } \\
\text { (A) }\end{array}$ & $\begin{array}{l}\text { População } \\
\text { (B) }\end{array}$ & $\begin{array}{l}\text { Densidade } \\
\text { (B/A) }\end{array}$ & $\begin{array}{l}\text { IDH } \\
\text { médio }\end{array}$ & $\begin{array}{c}\text { PIB } \\
\text { (milhões de R\$) }\end{array}$ \\
\hline Araranguá & $2.962,214$ & 160.169 & 54,1 & 0,797 & 1.339 \\
\hline Blumenau & $4.752,975$ & 547.591 & 115,2 & 0,843 & $7 \cdot 365$ \\
\hline Campos de Lages & $15 \cdot 726,01$ & 284.952 & 18,1 & 0,789 & 2.558 \\
\hline Canoinhas & $9.42,322$ & 232.513 & 24,7 & 0,768 & 2.143 \\
\hline Chapecó & $6.045,92$ & 361.345 & 59,8 & 0,819 & 4.645 \\
\hline Concórdia & $3.058,72$ & 137.892 & 45,1 & 0,827 & 2.707 \\
\hline Criciúma & $2.089,38$ & 324.747 & 155,4 & 0,813 & $3 \cdot 356$ \\
\hline Curitibanos & $6.505,93$ & 115.999 & 17,8 & 0,766 & 1.201 \\
\hline Florianópolis & $2.488,59$ & 709.941 & 285,3 & 0,852 & 6.488 \\
\hline Itajaí & $1.452,29$ & 404.854 & 278,8 & 0,817 & 3.468 \\
\hline Ituporanga & $1.530,19$ & 51.223 & 33,8 & 0,797 & 440 \\
\hline Joaçaba & $9.136,38$ & 304.043 & 33,3 & 0,807 & $5 \cdot 312$ \\
\hline Joinville & $4 \cdot 617,33$ & $697 \cdot 315$ & 147,1 & 0,846 & 11.289 \\
\hline Rio do Sul & $5 \cdot 267,57$ & 182.547 & 34,7 & 0,81 & 1.824 \\
\hline São Bento do Sul & $1.900,12$ & 114.778 & 60,4 & 0,815 & 1.574 \\
\hline São Miguel d'Oeste & $4.241,99$ & 171.160 & 40,3 & 0,797 & 1.646 \\
\hline Tabuleiro & $2.383,15$ & 23.336 & 9,8 & 0,779 & 176 \\
\hline Tijucas & $2.127,69$ & 69.874 & 32,8 & 0,813 & 647 \\
\hline Tubarão & $4.657,66$ & 337.775 & 72,5 & 0,814 & 2.513 \\
\hline Xanxerê & $4.805,76$ & 142.326 & 29,6 & 0,791 & 1.600 \\
\hline
\end{tabular}

Fonte: Elaboração própria a partir de: População IBGE/2000, PIB IBGE/2003 e IDH médio Pnud/200o.

A região Sul do Estado é composta por três microrregiões, Criciúma, Tubarão e Araranguá, que representam 11,5\% do PIB do Estado, 10\% da área geográfica e 15\% da população. O PIB microrregional está concentrado nos municípios que dão nome às microrregiões.

A mesorregião do Vale do Itajaí, composta pelas microrregiões de Blumenau, Itajaí, Rio do Sul e Ituporanga, destaca-se por concentrar cerca de $20 \%$ do PIB em 14\% da área geográfica do Estado.

A mesorregião Norte é composta por três microrregiões, Canoinhas, São Bento do Sul e Joinville. Concentra 25\% do PIB e 19\% da população em 16\% da área geográfica do território.

Finalmente, a mesorregião de Florianópolis, composta pelas microrregiões de Florianópolis, Tabuleiro e Tijucas, responde por 11\% do PIB, concentrados em 7,3\% do território do Estado e que abriga 15\% de sua população.

A Figura 1 do anexo mostra a localização das microrregiões e a Figura 2, o PIB per capita municipal. Percebe-se que as duas microrregiões mais ricas do 
Estado e que são vizinhas, são também as que desfrutam de melhor distribuição da renda, quais sejam, Joinville e Blumenau. Os dois municípios que dão nome às microrregiões são locais do início do processo de industrialização catarinense e atualmente abrigam empresas líderes na produção de têxteis, materiais elétricos, plásticos e de softwares. Como é natural nos processos de formação das cidades, o fluxo migratório de pessoas em busca de oportunidades e de firmas fornecedoras promove um encarecimento dos recursos locais, como aluguel da terra, por exemplo (Jacobs 1969). Com isso, se segue um espraiamento das atividades produtivas complementares para o entorno do local mais industrializado. Isso explica a melhor distribuição do PIB per capita entre os municípios que compõem as microrregiões de Joinville e Blumenau em relação a outras microrregiões do Estado. Esse mesmo processo parece ter ocorrido, em menor medida, no Sul do Estado, especificamente em Criciúma, município sede de grandes firmas da cadeia produtiva de cerâmica de revestimento, mas também na região Oeste, principalmente nos entornos dos municípios de Chapecó e Concórdia, municípios sede de grandes firmas exportadoras de carnes.

Por outro lado, esse processo não ocorreu nos entornos do município de Lages, ${ }^{11}$ o único em sua microrregião (Campos de Lages) com PIB per capita $\mathrm{R} \$ 335 \cdot{ }^{12}$

Na Figura 2 do anexo, as três manchas mais escuras apontam as regiões com a pior distribuição de renda do Estado. Como veremos a seguir, nesses locais (que congregam parte das microrregiões de Canoinhas ao Norte, Curitibanos e Campos de Lages na porção central do território e parte das microrregiões de Chapecó e São Miguel do Oeste no extremo sul), as principais atividades econômicas de transformação são intensivas em recursos naturais, notadamente, madeira.

O resultado final, aplicados os diversos procedimentos explicitados na seção 2 , apresenta 32 aglomerações produtivas, em 10 setores diferentes, localizadas em 16 microrregiões. As Figuras 3 e 4 do anexo apontam a localização específica das aglomerações industriais selecionadas pela metodologia em 10 mapas.

Os dois quadros a seguir resumem estes resultados. Os quadros são exibidos em ordem decrescente segundo características da diversidade produtiva setorial e da densidade de firmas das aglomerações. O primeiro quadro contém os resultados da aplicação do modelo aos setores de bens intermediários e de produção, e o segundo quadro resume os resultados dos setores de bens de consumo. 


\subsection{Aglomerações produtivas de bens intermediários e de produção}

Marcados pela intensidade do uso de capital em relação à mão de obra nos processos produtivos, os setores de bens intermediários e de capital, por sua característica de fornecedores especializados (Pavitt 1984), tendem a se aglomerar em regiões de intensa dinâmica econômica. Em Santa Catarina, cinco aglomerações "altamente diversificadas", segundo o número de segmentos produtivos que as compõe, estão localizadas nas microrregiões de Joinville, nas indústrias eletro-metal-mecânica, de artigos plásticos e na química; de Blumenau, na indústria eletro-metal-mecânica; e de Florianópolis, na informática.

O processo de industrialização de Joinville e Blumenau permitiu que as estruturas produtivas altamente densas se espalhassem por municípios contíguos. As estruturas contemplam firmas capazes de desenvolver desde as atividades produtivas mais elementares até algumas de alta complexidade tecnológica.

As diversas atividades produtivas da aglomeração de Tecnologias da Informação e Comunicação estão concentradas no município de Florianópolis devido ao apoio institucional cristalizado na presença de entidades públicas e privadas. A formação de mão de obra explica o volume de micro e pequenas firmas, sobretudo, na Universidade Federal de Santa Catarina. A demanda dessas firmas é para a solução de problemas técnicos de média e baixa complexidade, típicos de firmas, entidades governamentais e até de pessoas físicas.

A amplitude da produção da aglomeração produtiva de artigos plásticos de Joinville, formada por 183 firmas, encontra demanda na estrutura produtiva bastante diversificada da própria região. Assim como a aglomeração produtiva do setor químico de Joinville, que, apesar de menos densa, apresenta um conjunto de firmas de porte diversificado capaz de dinamizar processos locais de aprendizagem.

Além dessas estruturas altamente diversificadas, outras quatro classificadas como "diversificadas" foram identificadas: no Sul do Estado, as aglomerações de artigos plásticos, químico e metal-mecânico (Criciúma); e em Rio do Sul, as firmas da indústria metal-mecânica.

Nas atividades químicas e metal-mecânica do Sul do Estado, a localização das firmas, ao nível do município, segue a dispersão da estrutura produtiva de cerâmica de revestimento, à qual parte das firmas destina grande parcela de suas produções. O setor metal-mecânico é formado especialmente por firmas de micro e pequeno porte voltadas desde as atividades elementares, como as de metalurgia básica, até a produção de M\&E para a indústria ceramista. A estrutura produtiva do setor químico é composta por quatro firmas de médio porte entre as 107, é especializada na produção de coloríficos químicos para a produção de cerâmicas de revestimento. 
A produção de artigos plásticos da região Sul contempla, em especial, os segmentos de plásticos descartáveis e embalagens plásticas, atividades tecnologicamente mais elementares do que as de Joinville. Concentra-se em Criciúma e contempla firmas de grande porte, também líderes nacionais na produção de utensílios plásticos descartáveis.

Localizada em microrregião contígua à de Blumenau, a estrutura produtiva do setor metal-mecânico de Rio do Sul está concentrada nesse município e contempla sobretudo atividades de baixo/médio dinamismo tecnológico. Mas conta com um importante conjunto de firmas de grande e médio porte (Quadro 1).

\section{QUADRO 1 - CARACTERÍSTICAS DAS AGLOMERAÇÕES PRODUTIVAS CATARI- NENSES DOS SETORES DE BENS INTERMEDIÁRIOS E DE PRODUÇÃO}

\begin{tabular}{|c|c|c|c|c|c|c|c|}
\hline microrregião-setor & $\begin{array}{c}\text { Amplitude da } \\
\text { produção }^{13}\end{array}$ & $\begin{array}{l}\text { Densidade e Importân- } \\
\text { cia setorial no emprego } \\
\text { da microrregião }\end{array}$ & Micro & Peq. & Médias & Grandes & $\begin{array}{l}\text { Dispersão } \\
\text { Regional }^{14}\end{array}$ \\
\hline $\begin{array}{l}\text { Joinville - Eletro, } \\
\text { Metal, Mecânico }\end{array}$ & Alta Diversificação & $\begin{array}{c}940 \text { empresas - } 22,34 \% \\
\text { PFT }\end{array}$ & 765 & 147 & 21 & 13 & $\begin{array}{c}\text { Alta } \\
\text { Dispersão }\end{array}$ \\
\hline $\begin{array}{l}\text { Blumenau - Metal, } \\
\text { Mecânico }\end{array}$ & Alta Diversificação & 465 empresas - 5,27\% PFT & 398 & 52 & 11 & 4 & Dispersa \\
\hline Florianópolis - TIC's & Alta Diversificação & 257 empresas - 2,32\% PFT & 230 & 22 & 2 & 1 & Concentrada \\
\hline Joinville - Plástico & Alta Diversificação & 183 empresas - 4,68\% PFT & 115 & 45 & 19 & 4 & Concentrada \\
\hline Joinville - Químico & Alta Diversificação & 54 empresas - o,72\% PFT & 41 & 8 & 5 & o & Dispersa \\
\hline $\begin{array}{l}\text { Criciúma - Metal, } \\
\text { Mecânico }\end{array}$ & Diversificada & 225 empresas - 3,07\% PFT & 202 & 21 & 2 & o & Dispersa \\
\hline $\begin{array}{l}\text { Rio do Sul - Metal, } \\
\text { Mecânico }\end{array}$ & Diversificada & 150 empresas - $7,69 \%$ PFT & 123 & 20 & 6 & 1 & Concentrada \\
\hline $\begin{array}{l}\text { Sul do Estado } \\
\text { (Criciúma e Tubarão) } \\
\text { - Plástico }\end{array}$ & Diversificada & $\begin{array}{c}143 \text { empresas - Criciúma } \\
\text { 4,52\% PFT, Tubarão } \\
\text { 5,24\%PFT }\end{array}$ & 94 & 32 & 14 & 3 & Concentrada \\
\hline $\begin{array}{l}\text { Sul do Estado } \\
\text { Criciúma e Tubarão) - } \\
\text { Químico }\end{array}$ & Diversificada & $\begin{array}{c}107 \text { empresas - Criciúma } \\
\text { 1,79\% PFT, Tubarão } \\
\text { o,62\% PFT }\end{array}$ & 86 & 14 & 4 & o & Dispersa \\
\hline Blumenau - Software & Especializada & 227 empresas o,89\% PFT & 208 & 18 & 1 & o & Concentrada \\
\hline Joinville - Software & Especializada & 207 empresas o,87\% PFT & 185 & 20 & 2 & o & Concentrada \\
\hline Chapecó - Metalúrgico & Especializada & 156 empresas $1,84 \%$ PFT & 140 & 15 & 1 & o & Concentrada \\
\hline
\end{tabular}

Fonte: Elaboração própria com base na RAIS/MTE/2003.

13 A amplitude produtiva foi dividida em diversificada, pouco diversificada ou especializada. De "Alta diversificação" incluem-se as aglomerações com grande densidade de firmas voltadas a mais do que 3 (três) classes da CNAE. "Diversificadas", quando houve concentração em duas ou três classes CNAE, e "especializadas", quando uma das classes da CNAE esteve concentrada.

14 A dispersão regional das atividades tem a seguinte classificação: concentrada em mais de três municípios = "alta dispersão". Concentrada em três municípios = "dispersa" e concentrada em apenas um ou dois município = "concentrada". 
As firmas das aglomerações de software de Joinvile e Blumenau e de metalurgia em Chapecó apresentam alta especialização produtiva em seus segmentos e estão concentradas no principal município. As estruturas produtivas bastante densas. Formadas por firmas de micro, pequeno e médio porte destinam grande parte de suas produções à demanda local. Em Joinville e Blumenau, a diversificação industrial e a dinâmica das cidades são, por si só, geradoras de demandas capazes de sustentar novos adensamentos dessas aglomerações. Ao passo que, em Chapecó, as atividades estão destinadas a elos menos dinâmicos da produção local, de alimentos, móveis, madeira e construção civil.

\subsection{As Aglomerações Produtivas Catarinenses dos Setores de Bens de Consumo}

As informações do Quadro 2 revelam que, dentre as aglomerações produtoras de bens de consumo, apenas a têxteis/vestuários de Blumenau, com 2.730 firmas, é altamente diversificada. Entre os diversos segmentos da cadeia produtiva ali presentes, destaca-se um grupo de firmas líderes nacionais nos segmentos de cama, mesa, banho e vestuário. A atividade iniciada há mais de um século está atualmente dispersa em diversos municípios da região.

Apenas 4 aglomerações foram classificadas como diversificadas, segundo as amplitudes de suas produções: têxtil/vestuarista em Joinville, madeira em Canoinhas, Joaçaba e Rio do Sul e a calçadista de Araranguá. A alta densidade de firmas das duas primeiras congrega firmas de grande e médio porte, dispersas pelos municípios das microrregiões. Há também grande relevância do emprego gerado em suas microrregiões. Em Joinville, a percentagem superou os $10 \%$ e em Canoinhas superou os $20 \%$.

A aglomeração madeireira da microrregião de Joaçaba está concentrada no município de Caçador e é formada por pouco mais de 200 firmas, sendo 6 de médio porte e 3 de grande porte. A atividade representa em torno de $7 \%$ do emprego gerado na região. Já a aglomeração de Rio do Sul está concentrada no município de Ibirama e possui cerca de 200 firmas, de micro, pequeno e médio porte, que, no total, respondem por cerca de $7 \%$ do emprego da microrregião. Nas duas regiões, além das atividades de desdobramento de madeira, produzem-se também esquadrias para a construção civil.

A atividade couro/calçadista das firmas aglomeradas no município de Araranguá está voltada à produção de calçados, couro e outros artefatos de couro. A estrutura produtiva de 81 firmas representa $7,95 \%$ do emprego local e está, em boa parte, integrada à cadeia produtiva do aglomerado gaúcho do Vale dos Sinos.

O Quadro 2 aponta também a aglomeração de confecções do Sul do Estado como a de maior densidade, composta por firmas especializadas em con- 
fecções dispersas nos municípios das microrregiões de Criciúma, Tubarão e Araranguá. As atividades, mais elementares do que as desenvolvidas por firmas têxteis de Blumenau e Joinville, são realizadas por mais de 950 firmas, sendo apenas uma delas de grande porte e 15 de médio porte.

A atividade ceramista do Sul do Estado surgiu da abundância do insumo básico (argila). Duas atividades produtivas derivaram-se imediatamente, uma mais elementar, de cerâmica vermelha, telhas, tijolos etc., e outra, com processo produtivo mais complexo, de cerâmica de revestimento, que atualmente abriga um dos aglomerados produtivos mais dinâmicos do mundo formados pelas empresas locais de grande e médio porte.

As 374 firmas da aglomeração moveleira de São Bento do Sul, especializadas na produção de móveis de madeira, estão dispersas entre os municípios da microrregião e respondem por mais de $25 \%$ do emprego local.

No Oeste do Estado as firmas, também especializadas na produção de móveis e madeira, estão dispersas pelos municípios das microrregiões de São Miguel d'Oeste e Chapecó. As mais de 550 firmas respondem por 5,12\% dos empregos gerados na microrregião de São Miguel d' Oeste e 4,34\% da microrregião de Chapecó.

A única aglomeração de Itajaí é especializada em pescado. Nela, firmas de grande e médio porte exercem certa governança das atividades locais através da compra da produção de micro e pequenas firmas. As 250 firmas concentradas nos municípios de Itajaí e Navegantes respondem por cerca de 6\% do emprego gerado na microrregião.

As firmas da aglomeração produtiva madeireira da microrregião de Lages são especializadas no desdobramento da madeira. A estrutura de 203 firmas está, mormente, concentrada no município de Lages e responde por $9,3 \%$ do emprego formal gerado no local.

Na microrregião de Tubarão, as atividades madeireiras se concentram no município de Braço do Norte. A estrutura produtiva de 200 firmas é marcada pela presença de produtoras de "molduras de madeira" e representa $6 \%$ do emprego gerado na microrregião.

Na microrregião de Curitibanos, a aglomeração é formada por 165 firmas especializadas, sobretudo, no desdobramento de madeira. As firmas dispersas nos municípios de Monte Carlo, Santa Cecília e Curitibanos representam 22,3\% do emprego da microrregião.

A aglomeração de firmas da indústria calçadista da microrregião de Tijucas é formada por pouco mais do que 150 firmas, localizadas no município de São João Batista e especializadas na produção de calçados de couro.

A outra aglomeração produtiva inserida na microrregião de Tijucas é formada por empresas de micro, pequeno e médio porte, direcionadas à produção de 
cerâmica vermelha. A firma de grande porte é voltada à produção de cerâmica de revestimento. A atividade, bastante elementar do ponto de vista da base técnica de conhecimentos necessária à produção, responde por cerca de 17,8\% dos empregos gerados na região.

A aglomeração de firmas ceramistas de Rio do Sul está voltada a atividades de produção de cerâmica vermelha. A estrutura produtiva formada por 88 firmas é composta, quase que exclusivamente, por firmas de micro e pequeno porte que respondem por apenas $2,94 \%$ do emprego da microrregião.

QUADRO 2 - CARACTERÍSTICAS DAS AGLOMERAÇÕES PRODUTIVAS CATARINENSES DOS SETORES DE BENS DE CONSUMO

\begin{tabular}{|c|c|c|c|c|c|c|c|}
\hline Microrregião-setor & $\begin{array}{l}\text { Amplitude da } \\
\text { produção }\end{array}$ & $\begin{array}{c}\text { Densidade e importân- } \\
\text { cia setorial no emprego } \\
\text { da microrregião }\end{array}$ & Micro & Peq. & Médias & Grandes & $\begin{array}{l}\text { Dispersão } \\
\text { regional }\end{array}$ \\
\hline $\begin{array}{l}\text { Blumenau - Têxtil, } \\
\text { Confecções }\end{array}$ & Alta Diversificação & $\begin{array}{c}2730 \text { empresas - } 32,7 \% \\
\text { PFT }^{15}\end{array}$ & 2673 & 422 & 68 & 21 & $\begin{array}{c}\text { Alta } \\
\text { Dispersão }\end{array}$ \\
\hline $\begin{array}{l}\text { Joinville - Têxtil, } \\
\text { Confecções }\end{array}$ & Diversificada & 714 empresas - $11,67 \%$ PFT & 580 & 97 & 30 & 7 & Dispersa \\
\hline $\begin{array}{l}\text { Canoinhas - Produtos de } \\
\text { Madeira }\end{array}$ & Diversificada & 324 empresas - 20,85\% PFT & 264 & 43 & 14 & 3 & Dispersa \\
\hline Joaçaba - Madeira & Diversificada & 209 empresas $-7,30 \%$ PFT & 169 & 31 & 6 & 3 & Concentrada \\
\hline Rio do Sul - Madeira & Diversificada & 199 empresas - 6,99\% PFT & 161 & 34 & 4 & o & Concentrada \\
\hline Araranguá - Calçados & Diversificada & 81 empresas $-7,95 \%$ PFT & 63 & 14 & 4 & o & Concentrada \\
\hline $\begin{array}{l}\text { Região Sul (Araranguá, } \\
\text { Criciúma e Tubarão) - } \\
\text { Confecções }\end{array}$ & Especializada & $\begin{array}{c}963 \text { empresas - Araranguá } \\
\text { 8,41\% PFT, Criciúma 9,39\% } \\
\text { PFT, Tubarão 6,06\% PFT }\end{array}$ & 794 & 153 & 15 & 1 & Dispersa \\
\hline $\begin{array}{l}\text { Sul do Estado (Araranguá, } \\
\text { Criciúma e Tubarão) - } \\
\text { Cerâmico }\end{array}$ & $\begin{array}{l}\text { Especializada } \\
\text { (Cerâmica de } \\
\text { Revestimento) } \\
\text { Especializada (Ce- } \\
\text { râmica Vermelha) }\end{array}$ & $\begin{array}{c}\text { 498 empresas - Araranguá } \\
\text { 3,09\% PFT, Criciúma 8,10\% } \\
\text { PFT, Tubarão 5,01\% PFT }\end{array}$ & 412 & 59 & 17 & 1 & $\begin{array}{c}\text { Alta } \\
\text { Dispersão }\end{array}$ \\
\hline São Bento do Sul - Móveis & Especializada & 374 empresas - $26,85 \%$ PFT & 287 & 68 & 18 & 1 & Dispersa \\
\hline $\begin{array}{l}\text { Extremo Oeste (São Mi- } \\
\text { guel d'Oeste e Chapecó) } \\
\text { - Móveis }\end{array}$ & Especializada & $\begin{array}{c}338 \text { empresas - São Miguel } \\
\text { d'Oeste 5,12\% PFT } \\
227 \text { empresas - Chapecó } \\
4,34 \% \text { PFT }\end{array}$ & 415 & 150 & 3 & o & $\begin{array}{c}\text { Alta } \\
\text { Dispersão }\end{array}$ \\
\hline Itajaí - Pescados & Especializada & 250 empresas - $6,02 \%$ PFT & 214 & 25 & 9 & 2 & Concentrada \\
\hline $\begin{array}{l}\text { Campos de Lages - } \\
\text { Madeira }\end{array}$ & Especializada & 203 empresas - 9,36\% PFT & 159 & 37 & 5 & 2 & Concentrada \\
\hline Tubarão - Molduras & Especializada & 200 empresas - 6,01\% PFT & 169 & 22 & 9 & o & Concentrada \\
\hline Curitibanos - Madeira & Especializada & 165 empresas - 22,30\% PFT & 123 & 36 & 5 & 1 & Dispersa \\
\hline Tijucas - Calçados & Especializada & 157 empresas - $15,93 \%$ PFT & 130 & 20 & 7 & o & Concentrada \\
\hline Tijucas - Cerâmico & Especializada & 126 empresas - 17,81\% PFT & 114 & 10 & 1 & 1 & Concentrada \\
\hline Rio do Sul - Cerâmico & $\begin{array}{l}\text { Especializada (Ce- } \\
\text { râmica Vermelha) }\end{array}$ & 88 empresas - 2,94\% PFT & 69 & 18 & 1 & o & Concentrada \\
\hline
\end{tabular}

Fonte: Elaboração própria com base nos dados da RAIS/2003. 


\subsection{A aplicação do Índice de Adensamento Estrutural \\ (IAE)}

Por se tratar de um índice que procura avaliar e comparar características internas do adensamento estrutural da aglomeração produtiva de mesmo setor, organizou-se a apresentação dos resultados da aplicação do IAE de acordo com os setores considerados na análise. O índice não é homogêneo por setor. No setor cerâmico, por exemplo, há uma aglomeração muito densa (Criciúma), ao lado de aglomerações menos densas (Rio do Sul e Tijucas). O mesmo não acontece com o setor madeireiro cuja relativamente baixa densidade é comum às diversas aglomerações.

O Quadro 3 apresenta os resultados da aplicação do IAE nas três aglomerações têxteis. $\mathrm{O}$ alto valor em Blumenau resulta da intensa presença de firmas produtoras de $\mathrm{M} \& \mathrm{E}$, bem como da alta densidade e diversificação produtiva intersetorial. As características dos processos de aprendizagem locais sugerem que a estrutura menos densa de Joinville é beneficiada pela proximidade com Blumenau (Bittencourt et al. 2008). No Sul do Estado, a especialização produtiva em artigos de confecção parece não estimular a inserção de firmas produtoras de M\&E no local, o que explica o IAE mais baixo.

QUADRO 3. APLICAÇÃO DO IAE ÀS AGLOMERAÇÕES TÊXTEIS CATARINENSES

\begin{tabular}{|l|c|}
\hline \multicolumn{1}{|c|}{ Microrregião-setor } & Indicador de Adensamento Estrutural \\
\hline Blumenau - Têxtil, Confecções & 689,2 \\
\hline Joinville - Têxtil, Confecções & 43,7 \\
\hline Região Sul (Araranguá, Criciúma e Tubarão) - Confecções & 21,4 \\
\hline
\end{tabular}

Fonte: Elaboração própria

Entre as aglomerações do setor moveleiro (Quadro 4), em São Bento do Sul, a estrutura é adensada pela presença de 5 produtoras de M\&E. No Oeste do Estado, as duas produtoras de M\&E compõem uma aglomeração menos densa apenas do que a de São Bento do Sul. O valor de 19,7 registrado em Rio do Sul se deve mais à densidade e ao porte de firmas produtoras de móveis do que a presença das três produtoras de M\&E. Ao passo que, em Araranguá, a restrita densidade empresarial aliada à ausência de produtores de M\&E indicam o menor potencial de ganhos interativos interfirmas. 
QUADRO 4. APLICAÇÃO DO IAE ÀS AGLOMERAÇÕES MOVELEIRAS CATARINENSES

\begin{tabular}{|l|c|}
\hline \multicolumn{1}{|c|}{ Microrregião-setor } & Indicador de Adensamento Estrutural \\
\hline São bento do Sul - Móveis & 79 \\
\hline Extremo Oeste (São Miguel d'Oeste e Chapecó) - Móveis & 35,7 \\
\hline Rio do Sul e Curitibanos - Móveis & 19,72 \\
\hline Araranguá - Móveis & 1,1 \\
\hline
\end{tabular}

Fonte: Elaboração própria

No setor madeireiro (Quadro 5), a importância do IAE foi de diferenciar estruturas com densidades bastante semelhantes.

As 374 firmas de Canoinhas adensadas por 5 produtoras de M\&E explicam o maior IAE do setor $(53,6)$. Já em Rio do Sul, apesar de o número de firmas ser de pouco mais da metade de Canoinhas, o porte médio das 4 produtoras de maquinário explica o valor de 44,3 do IAE.

A interatividade é também estimulada na microrregião de Tubarão, onde, além das 200 madeireiras, encontram-se 5 produtores de M\&E. Já na microrregião de Joaçaba, a aglomeração de 109 firmas é adensada por, apenas, dois produtores de M\&E, que, por empregarem um volume médio de trabalhadores, superior ao das firmas de Tubarão, apresentou um IAE muito próximo ao dessa microrregião, de 23,2.

Os dois produtores de $\mathrm{M} \& \mathrm{E}$ de Curitibanos são de pequeno porte e adensam uma estrutura de apenas 165 firmas. Enquanto que, em Lages, a estrutura produtiva de 203 firmas não conta com produtores de M\&E. Tais fatores apontam para a possível existência de certa complementaridade entre as estruturas produtivas vizinhas. Mesmo assim, seus IAE's são os mais baixos entre as aglomerações analisadas, de 8,7 em Curitibanos e 6,99 em Lages.

QUADRO 5. APLICAÇÃO DO IAE ÀS AGLOMERAÇÕES MADEIREIRAS CATARINENSES

\begin{tabular}{|l|c|}
\hline \multicolumn{1}{|c|}{ Microrregião-setor } & Indicador de Adensamento Estrutural \\
\hline Canoinhas - Madeira & 53,6 \\
\hline Rio do Sul - Madeira & 44,8 \\
\hline Tubarão - Molduras & 23,3 \\
\hline Joaçaba - Madeira & 23,2 \\
\hline Curitibanos - Madeira & 8,7 \\
\hline Campos de Lages - Madeira & 6,99 \\
\hline
\end{tabular}

Fonte: Elaboração própria 
Para a análise do IAE das estruturas produtivas do setor de plásticos aglomeradas em Santa Catarina (Quadro 6), salienta-se que 7 das 9 firmas produtoras de M\&E não se encontram inseridas nas duas aglomerações identificadas. Possivelmente em virtude de parte de suas produções se destinarem a outros setores.

Tanto em Joinville quanto no Sul do Estado, apenas uma produtora de M\&E foi identificada. Pesou para a diferença do IAE, em favor da aglomeração de Joinville, a densidade e o porte médio das firmas produtoras de artigos plásticos.

QUADRO 6. APLICAÇÃO DO IAE ÀS AGLOMERAÇÕES DE PLÁSTICOS CATARINENSES

\begin{tabular}{|l|c|}
\hline \multicolumn{1}{|c|}{ Microrregião-setor } & Indicador de Adensamento Estrutural \\
\hline Joinville - Plástico & 112,9 \\
\hline Sul do Estado (Criciúma e Tubarão) - Plástico & 70,3 \\
\hline
\end{tabular}

Fonte: Elaboração própria

No setor de cerâmica de revestimento, a diferença substancial do volume de firmas inseridas nas aglomerações de cerâmica de revestimento e cerâmica vermelha do Sul do Estado, em relação às aglomerações das microrregiões de Tijucas e Rio do Sul, é ressaltada pelo IAE (Quadro 7). Seis, das nove firmas catarinenses produtoras de M\&E, estão na região Sul. Em Rio do Sul, apenas uma produtora de M\&E adensa a estrutura de 88 firmas, que obteve o IAE de 6,69 . Valor ainda menor do que o de Tijucas, que não conta com produtoras de M\&E, mas é composta por mais de 120 firmas.

QUADRO 7. APLICAÇÃO DO IAE ÀS AGLOMERAÇÕES DE CERÂMICA CATARINENSES

\begin{tabular}{|l|c|}
\hline \multicolumn{1}{|c|}{ Microrregião-setor } & Indicador de Adensamento Estrutural \\
\hline Sul do Estado (Criciúma, Tubarão e Araranguá) - Cerâmico & 582 \\
\hline Tijucas - Cerâmico & 7,9 \\
\hline Rio do Sul - Cerâmico & 6,69 \\
\hline
\end{tabular}

Fonte: Elaboração própria

\section{Conclusões}

O modelo usado neste trabalho identificou em Santa Catarina 32 aglomerações produtivas com suas densidades, porte das firmas, amplitude produtiva e diversificação regional. A análise de suas características revelou diferentes graus de especialização em aglomerações de um mesmo setor, mas localizadas em espaços diferentes, assim como, a distribuição da atividade entre os municípios da aglomeração. 
$\mathrm{O}$ indicador de adensamento estrutural foi capaz de sugerir diferenças nas composições produtivas internas das estruturas. Nos setores em que a diferença do indicador entre locais foi maior (têxtil e cerâmica), destacou-se o potencial das maiores aglomerações. Nos setores com melhor distribuição regional da estrutura produtiva, como o madeireiro, determinadas estruturas produtivas com menor densidade absoluta mostraram-se de maior potencial interativo.

Ainda assim, parecem adequadas novas tentativas para aprimorar o indicador. Tal desafio deve considerar a presença no local de outros elos das cadeias de produção e de estruturas de coordenação e conhecimentos associados à atividade principal.

A apresentação dos resultados em dois grupos de setores, bens intermediários e de produção e bens de consumo, revelou, nos primeiros, estruturas caracterizadas pela ampla diversificação da produção e, nos segundos, tendência de especialização.

As estruturas locais produtoras de bens intermediários e de produção estão concentradas nas regiões mais industrializadas, sobretudo, em Joinville e Blumenau, mas também em Criciúma. Além das estruturas produtivas mais densas e com elevado número de firmas de grande porte, os locais abrigam as aglomerações com maior dispersão de firmas na microrregião, o que pode estar indicando o deslocamento da atividade em favor de municípios contíguos. Fora do eixo Nordeste-Sul, as três aglomerações estão concentradas no maior município local. Em Rio do Sul e Chapecó, a concentração nos municípios sede aponta diversificação da atividade industrial estimulada pela especialização industrial pré-existente. Em Florianópolis, o estímulo é a estrutura institucional de conhecimento já desenvolvida (Bittencourt 2006).

Sob o ponto de vista do estímulo da aprendizagem por interação (Lundvall 1988) e (Lundvall \& Jonhson 1992), entende-se que, nesses locais (mais industrializados), o sistema de incentivos necessários ao aprofundamento das interações capazes de criarem linguagem específica que viabilize o fluxo de conhecimentos tácitos e ganhos mútuos de aprendizagem, é mais avançado do que no restante do Estado. Essa vantagem se amplia quando consideramos o tempo necessário ao estabelecimento de canais de confiança entre agentes interativos. Ou seja, a diversificação da estrutura produtiva local e os benefícios dos consequentes spillovers de conhecimento, estimuladores de novos incrementos de produtividade, inovação e crescimento (Jacobs 1969), não ocorrem repentinamente, mesmo que sejam objetivos efetivos de políticas de desenvolvimento local. Portanto, a densidade e a diversificação das atividades produtivas, que configuram estímulos "naturais" à aprendizagem e a inovação, são vantagens das microrregiões de Joinville, Blumenau e Criciúma.

Empiricamente, essa noção foi confirmada em análise de dados de uma tabulação especial da Pesquisa de Inovação Tecnológica (PINTEC) (Bittencourt et al. 
2008). Os resultados apontaram como as formas de interação e as inovações são mais frequentes e seus impactos mais consistentes, nesses locais. Além disso, o trabalho mostrou uso restrito da estrutura de C\&T mesmo entre as firmas que compõem tais estruturas. Nessa direção, a instituição de centros tecnológicos e científicos de excelência nesses locais e de mecanismos que estimulem a interação com a esfera produtiva deve ser prioridade às políticas de aprendizagem. Isso se deriva da compreensão de que, por se tratar de uma estrutura local capaz de interagir e inovar de maneira mais eficaz há ali um conjunto de capacitações mais adequadas à tarefa de absorver, utilizar e gerar novos conhecimentos a partir de interações com a esfera de C\&T. A recente criação de uma extensão da Universidade Federal de Santa Catarina, voltada aos cursos de engenharia, é exemplo de que essa compreensão é compartilhada. A expectativa, de ações como essas, é de que as inovações futuras agreguem maior volume de conhecimentos, além da ampliação do estoque de conhecimentos da firma e dos agentes de C\&T.

As aglomerações de produtores de bens de consumo, além de estarem em maior número, estão mais espalhadas no Estado. Com o auxílio das informações da Tabela 2 e da Figura 2 do Anexo 1, nota-se uma parcela significativa dessas aglomerações localizadas em microrregiões com PIB total e PIB per capita relativamente menores àquelas onde há aglomerações de bens intermediários e de produção. Nesses locais, o processo de adensamento e diversificação industrial é ainda incipiente e, muitas vezes, restrito a um único município.

Em tais, as prioridades normativas, capazes de diminuir as desigualdades regionais a médio e longo prazo, estariam associadas ao estabelecimento de mecanismos de incentivo à complementaridade produtiva e à diversificação industrial local, de maneira a criar ambiente mais fértil ao estabelecimento de práticas interativas frequentes, típicas dos processos de aprendizagem virtuosos $^{16}$.

Contudo, ainda que essas diretrizes sejam bastante recomendáveis, a restrição da caracterização estrutural, sob o ponto de vista da produção, dificulta sugestões de políticas mais consistentes. A identificação das estruturas institucionais de conhecimento e coordenação desses espaços locais, como também suas formas particulares de interação com as firmas, seriam pesquisas recomendáveis para um diagnóstico mais completo e uma consequente derivação normativa ainda mais adequada. prioridade normativa associada à ampliação do uso do estoque de recursos da esfera de C\&T, por já contarem com relativamente alta densidade de firmas aglomeradas e por estarem inseridas em locais industrialmente diversificados. Essa noção não se aplica à aglomeração de confecções do Sul do Estado, dada a dispersão local do número de firmas e a menor diversificação industrial. 


\section{Referências}

BITTENCOURT, P.F. (2006). "Dinâmica da inovação e arranjos produtivos locais: uma análise da distribuição da atividade industrial em Santa Catarina”. Dissertação de Mestrado. PPGE/UFSC. Florianópolis.

BITTENCOURT, P. \& CAMPOS, R. \& GUINTER, N. (2008). "Externalidades territoriais e processos locais de aprendizagem: uma análise exploratória”. Artigo vencedor do II Prêmio BRDE/CORECON-SC de Desenvolvimento Econômico. No prelo - Florianópolis.

BRITTO, J. \& ALBUQUERQUE, E. (2002). "Estrutura e dinamismo de clusters industriais na economia brasileira; uma análise exploratória a partir dos dados da RAIS”. Estudos Econômicos32 (1):71-102.

BRITTO, J. (2003). “Configuração espacial da indústria brasileira: uma análise baseada na noção de aglomerações produtivas". Trabalho apresentado no $8^{\circ}$ Encontro da Sociedade Brasileira de Economia Política. Florianópolis, junho.

CAMPOS, R. \& CÁRIO, S. \& NICOLAU, J. \& LINS, H. \& BARBOSA, C. (2002). "Reestruturação industrial e aglomerações setoriais locais em Santa Catarina". In: VIEIRA, P. (org.). A pequena produção e o modelo catarinense de desenvolvimento. Florianópolis, APED, pp. 113-170.

CASSIOLATO, J. \& LASTRES, H.M. (2003) “O foco em arranjos produtivos e inovativos locais de micro e pequenas empresas”. In: LASTRES, H.M. \& CASSIOLATO, J. \& MACIEL, M. (orgs). Pequena empresa: cooperação e desenvolvimento local. Rio de Janeiro. Relume Dumará, pp.21-34.

HADDAD, P. R. (1989). “Medidas de localização e de especialização”. In: HADDAD, P. R. et al. (Org.). Economia regional: teorias e métodos de análise. Fortaleza: BNB-ETENE.

JACOBS, J. (1969). The economy of the cities. Vintage Books, New York.

LUNDVALL, B. A. (1988). "Innovation as an interactive process: from user-producer interaction to the national system of innovation”. In: Dosi, G. et al. (orgs). Technical change and economic theory. London: Pinter Publishers, pp.349-369.

LUNDVALL, B. \& JOHNSON, B. (1992) “Closing the institutional gap?" Revue d'Economie Industrielle 59 (1): 111-123.

PAVITT, K. (1984). "Sectoral Patterns of technical change: towards a taxonomy and a theory”. Research Policy 13:343-373.

RAIS/MTE. RAIS (2003) - Relação Anual de informações sociais. MTE - Ministério do trabalho e emprego. Departamento de Emprego e Salários. Bases estatísticas. Brasília.

SUZIGAN, W. \& FURTADO, J. \& GARCIA, R. \& SAMPAIO, S. (2001). “Aglomerações industriais no estado de São Paulo”. Economia Aplicada 5(4):695-717.

SUZIGAN, W. \& FURTADO, J. \& GARCIA, R. \& SAMPAIO, S. (2002b). “Governança em sistemas de MPMEs em clusters industriais”. Rio de Janeiro: UFRJ. Relatório de pesquisa. URL:http:/www.fclar.inesp.br/pesq/grupos/geein/o2atividades/ 7pesquisacluster/geeino27.htm.

SUZIGAN, W. \& FURTADO, J. \& GARCIA, R. \& SAMPAIO, S. (2003a). "Coeficientes de Gini locacionais - GL: aplicação à indústria de calçados do estado de São 
Paulo". Nova Economia 13(2):39-60.

SUZIGAN, W. \& FURTADO, J. \& GARCIA, R. \& SAMPAIO, S. (2004). "Sistemas locais de produção: mapeamento, tipologia e sugestões de políticas.” Revista de Economia Política 24:543-562.

Submissão: 7 de junho 2007

Primeira resposta: 24 de agosto de 2007 Aceite: 20 de outubro de 2008 


\section{Anexo 1: Microrregiões Geográficas do IBGE de Santa Catarina}

FIGURA A1. MICRORREGIÕES GEOGRÁFICAS DO IBGE DE SANTA CATARINA

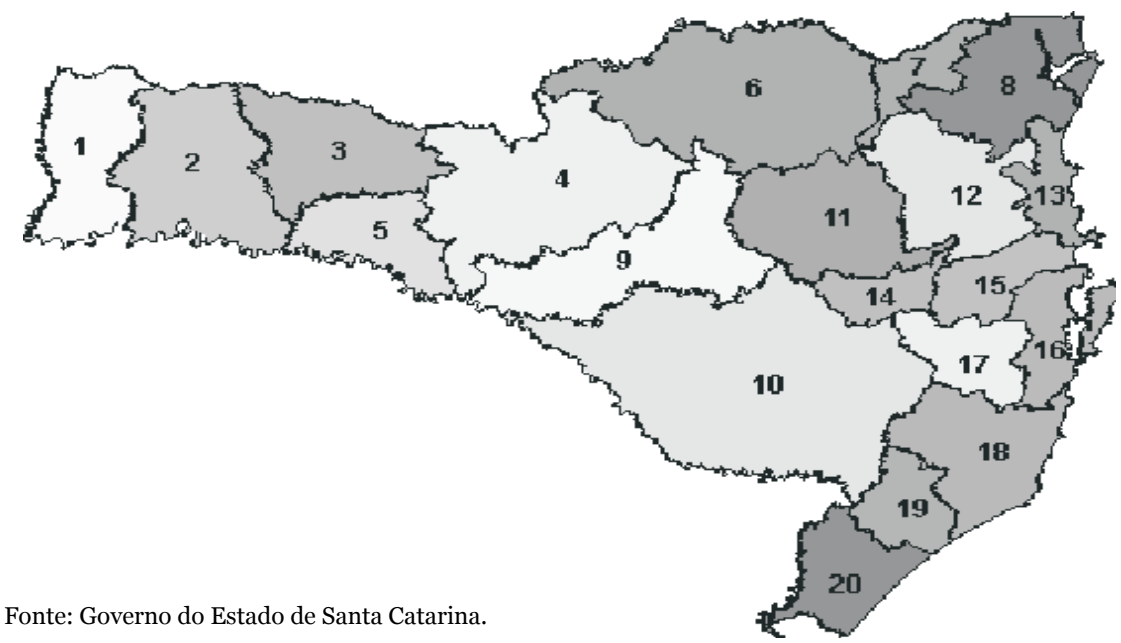

Legenda: 1- São Miguel d' Oeste, 2 - Chapecó, 3 - Xanxerê, 4 -Joaçaba, 5 - Concórdia, 6 - Canoinhas, 7 - São Bento do Sul, 8 - Joinville, 9 - Curitibanos, 10- Campos de Lages, 11 - Rio do Sul, 12 - Blumenau, 13 - Itajaí, 14 - Ituporanga, 15 - Tijucas, 16 - Florianópolis, 17 - Tabuleiro, 18 - Tubarão, 19 - Criciúma e 20 - Araranguá.

\section{FIGURA A2. PIB PER CAPITA MUNICIPAL CATARINENSE}

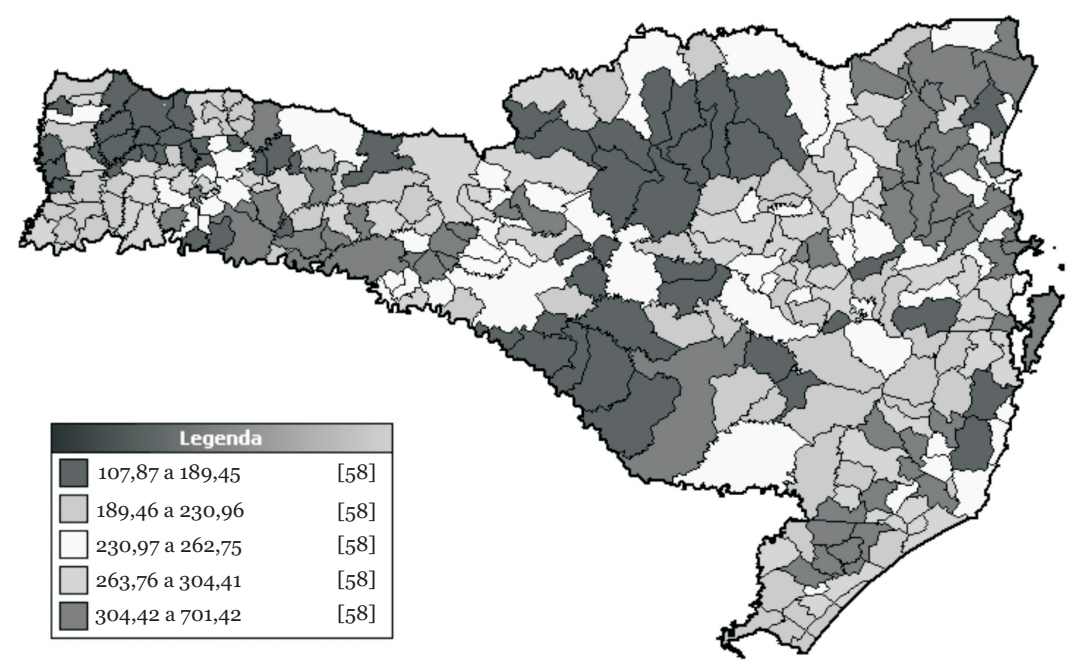

Fonte: Atlas do Desenvolvimento. 
FIGURA A3. AGLOMERAÇÕES PRODUTIVAS CATARINENSES DOS SETORES DE BENS DE CONSUMO

Aglomerações Produtivas Catarinenses de Produtos de Madeira

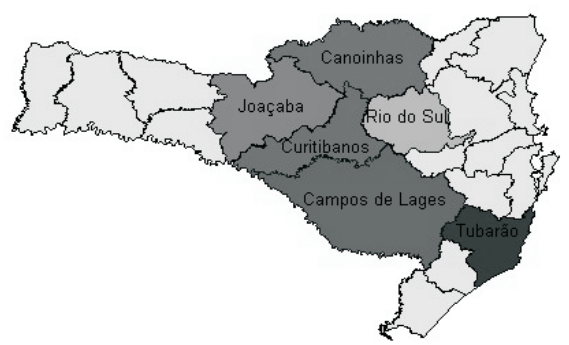

Aglomerações Produtivas Catarinenses Calçadistas

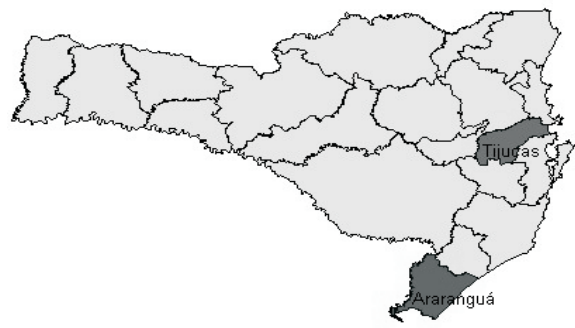

Aglomeração Produtiva Catarinense de Pescado

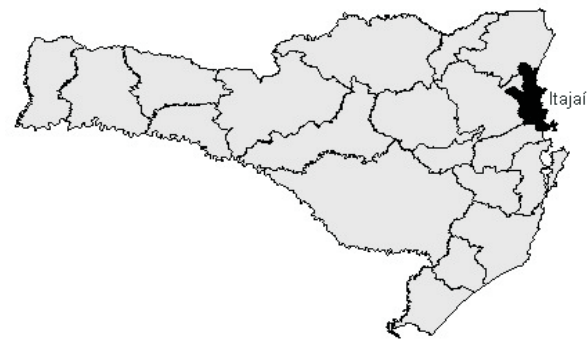

Aglomerações Produtivas

Catarinenses Moveleiras

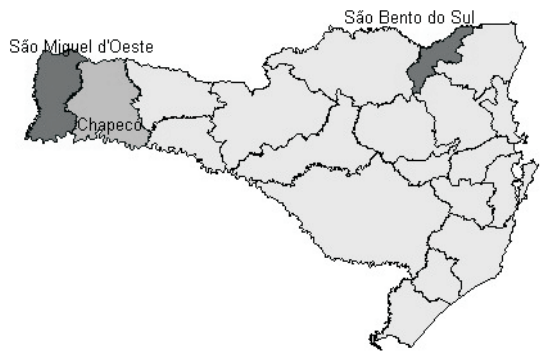

Aglomerações Produtivas Catarinenses de Produtos de Cerâmica

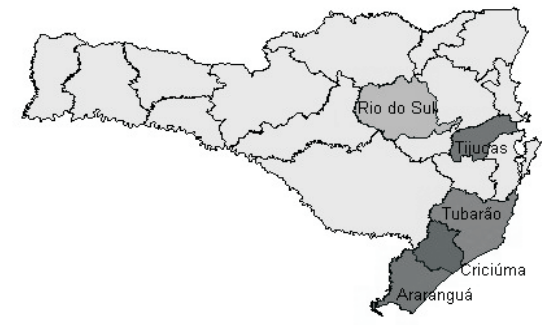

Aglomerações Produtivas Catarinenses de Têxteis/Confecções

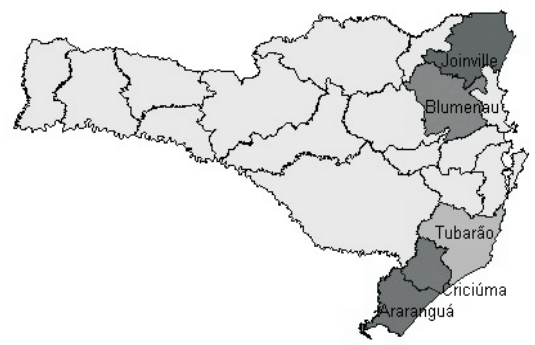

Fonte: Elaboração própria 
FIGURA A4. AGLOMERAÇÕES PRODUTIVAS CATARINENSES DOS SETORES DE BENS INTERMEDIÁRIOS E DE PRODUÇÃO

Aglomerações Produtivas

Catarinenses Eletro-Metal-Mecânica
Aglomerações Produtivas Catarinenses de Produtos Plásticos
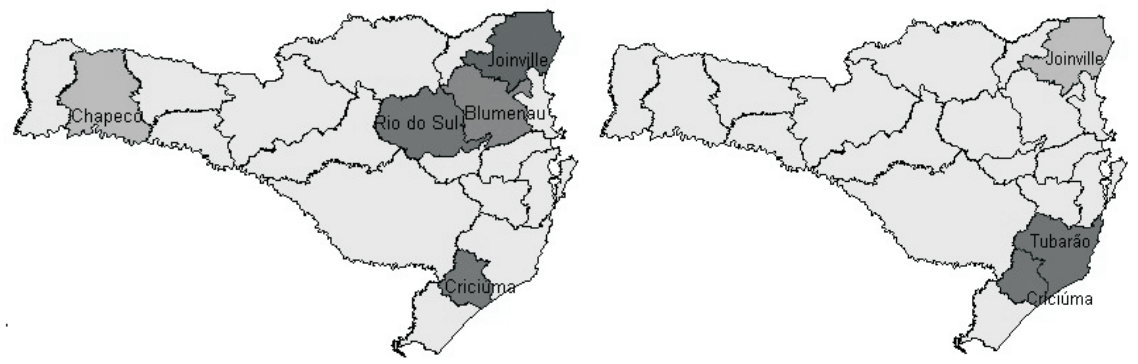

Aglomerações Produtivas

Catarinenses de Tecnologia da Informação e Comunicação

Aglomerações Produtivas Catarinenses de Produtos Químicos
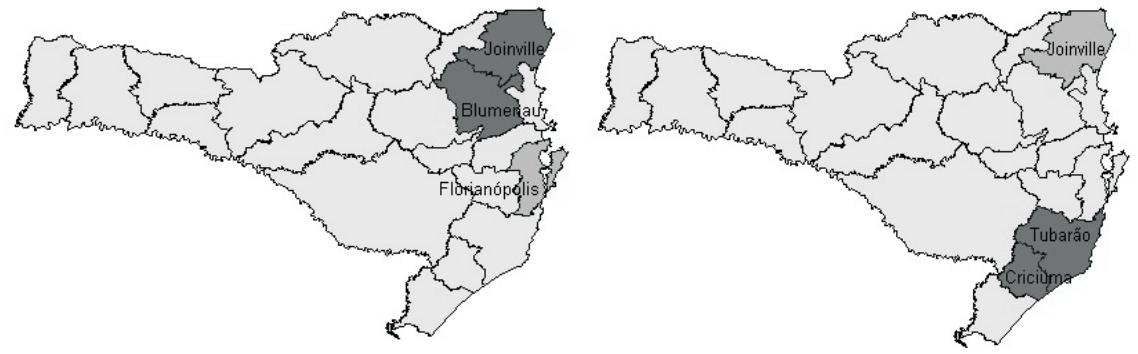

Fonte: Elaboração própria 
